\title{
The reconciliatory role of Holy Communion in the Methodist tradition
}

\author{
Author: \\ Wessel Bentley ${ }^{1}$ \\ Affiliation: \\ ${ }^{1}$ Department of Philosophy \\ and Systematic Theology, \\ University of South Africa, \\ South Africa \\ Correspondence to: \\ Wessel Bentley \\ Email: \\ wbentley@telkomsa.net \\ Postal address: \\ PO Box 905-1304, \\ Garsfontein 0042, \\ South Africa \\ Dates: \\ Received: 26 Jan. 2011 \\ Accepted: 02 Aug. 2011 \\ Published: 18 Oct. 2011 \\ How to cite this article: \\ Bentley, W., 2011, 'The \\ reconciliatory role of Holy \\ Communion in the Methodist \\ tradition', Verbum et Ecclesia \\ 32(2), Art. \#501, 6 pages. \\ http://dx.doi.org/10.4102/ \\ ve.v32i2.501 \\ Note: \\ Dr Wessel Bentley is a \\ part-time lecturer in the \\ Department of Philosophy \\ and Systematic Theology \\ at the University of \\ South Africa.
}

\begin{abstract}
Violence is an instrument of segregation, whether it manifests physically, emotionally, verbally or by any other means. Can the church be an instrument of reconciliation where people have been divided through violence? This article explores the reconciliatory role of the Sacrament of Holy Communion in the Methodist tradition, which has as a Christian denomination, experienced many threats of division in its history. Holy Communion, it is argued, is the one place where people, who may find every reason not to be together, are invited to share in an event which unites them.
\end{abstract}

\section{Introduction}

Violence never happens spontaneously. It does not happen without a cause, an attitude or some form of thinking process sparking a series of events that leads to circumstances where people are divided between those who are victims and those who act as offenders. Violence does not always manifest in physical harm being done by one person to another. Violent words, policies, attitudes and actions have the aim of violating the personhood of another whilst seeking to maintain the self in a position of prominence and of dominance. Violence therefore has relational consequences. The greater the act of violation or violence, the greater the relational gap created between offender and victim. In turn, the greater the relational gap between offender and victim, the greater the potential for acts of continued violation or of violence. This is the premise from which I define any form of segregation or notion of alienation.

It is from this definition of violence that this article explores the understanding of the role of Holy Communion as practiced by the Methodist tradition in order to bring people together who have been separated by the violence of abuse, segregation and even of prejudice. From the onset, I need to make it clear that this article does not aim to debate, refute or challenge the different understandings of the Sacrament of Holy Communion as practiced by other denominations or Christian traditions. The reader will note that there are many diverse interpretations of the celebration of the Sacrament of Holy Communion, each carrying a valid and justified reason for the way it is celebrated. The Christian church has a long history of dialogue on these issues and all of these have been worked through thoroughly and have credible reasons for their perspectives. As this article describes the theology of an Open Table in the Methodist tradition, it does so acknowledging these different understandings, but presents a theological position, which has been at the heart of the Methodist movement since the days of John Wesley.

Of course, to speak about theology within a tradition in such broad terms is dangerous. We know that in practice not all congregations and places of worship would necessarily identify with the views expressed here. This article follows the general understanding of the theology of the Lord's Supper in the Methodist tradition, which through its experience, especially in South Africa, has found the Sacrament to be a place and opportunity for healing, reconciliation and spiritual awakening.

\section{Examples of reconciliation in Southern African Methodism around the Lord's table}

Perhaps the most striking event in South African Methodism, where Communion plays a reconciliatory role, occurred during the Apartheid-era attempts to separate worshippers along racial lines. The Methodist Church of Southern Africa responded to this threat with the following statement, as recorded in the minutes of the Conference of the Methodist Church of Southern Africa (1958):

Like other parts of the life of our country, the church is facing choices which will determine her future development, and in particular the choice between unity and division. The Conference, in prayer and heart-searching, expressed its conviction that it is the will of God for the Methodist Church that it should be one and undivided, trusting in the leading of God to bring this ideal to ultimate fruition.

(Conference of the Methodist Church of Southern Africa 1958:202) (c) 2011. The Authors. Licensee: AOSIS OpenJournals. This work is licensed under the Creative Commons Attribution License. 
If, at the time, the Methodist Church succumbed to the pressure of a divided format of worship and fellowship, it would have experienced the reality of a divided Table. The implication would have been that those who supported the division would not have knelt at the same Table as those who had fallen victim to the State's policies. By making a pronouncement on being '.. one and undivided ...' (1958:202), the Methodist Church made a declaration about the nature of Communion within this tradition. People who had fundamental differences in their political views still found themselves kneeling side by side at the Table in Church. This pronouncement was a pivotal moment in the life of the Methodist movement in South Africa and the way it understood and celebrated the Sacrament. It certainly seemed to have set the tone for this denomination's further role in working towards reconciliation in a context of diversity.

The theme 'one and undivided' started as a description of the relationship between Christians of varied cultural backgrounds in this denomination, but had an outworking of reaching beyond denominational borders and inviting society at large to rethink its policies. Furthermore, it started to challenge the very understanding of what it means to be a Christian community made up of people, who by nature are not homogenous, but who differ in perspectives, cultures, races and gender. In the years following this statement, the notion of an undivided Table became central to the ordination of the first female minister in the Methodist church. It directed the debates surrounding infant baptism and believers' baptism, ultimately leading the church to conclude that both believers' and infant baptism were acceptable.

It seems that whenever there was a threat of division in the church, whether sparked by politics or doctrine, South African Methodists have resorted to the Communion Table. They did so first by acknowledging differences, but also to proclaim that despite divergent opinions, they are under the same divine grace symbolised through the act of kneeling together at the Lord's Table.

The notion of 'one and undivided' did not remain only amongst members of the denomination. It also became an instrument through which the Methodist people have come to show solidarity with those who have been marginalised and affected negatively by the violence of society at large. Not only has it shown solidarity, but it has been the witness of the unity which God's restorative grace can offer through the Sacrament.

One example can be found at the Central Methodist Mission. The brutality of the political regime in Zimbabwe and the xenophobic attacks of 2008 in South Africa sparked a huge influx of homeless people to the Central Methodist Mission situated in downtown Johannesburg. Here, besides being offered shelter, the homeless and victims of abuse were and are still invited to regular services of Holy Communion. It is at these services that people, who have been marginalised and directly affected by the violation of their humanity, are able to kneel alongside the people who identify themselves as ordinary members of the church and of society. The message is clear: although they are cast out by society at large, there is a place for all at the Lord's Table and it is through this Sacrament that they and all who kneel alongside them are seen in equal measures of love and grace by the Almighty.

In more recent times, as the church has engaged the controversial issue of its position on same-sex relationships, the church has called on its members to remain one and undivided (Methodist Church of Southern Africa 2006:75). The Lord's Table would once again be the place where people of divergent views would find unity in the love of God.

These are all examples of overt situations of violence and violation and how unity at the Table kept people together despite their differences. But the Open Table is more than this. There are many subtle forms of violence that take place in communities and families. The unspoken prejudicial attitudes which manifest in our manner, resentment, jealousy and hatred are amongst some of the vices which people harbour, and if they should choose, could use these as an excuse not to participate with another person in fellowship or even in a Sacrament of the Church. What then is an Open Table, and how does it facilitate reconciliation?

\section{What is the theology of an Open Table?}

For a detailed discussion on the theology of the Open Table, the most comprehensive work to be consulted is Stamm's book entitled Let every soul be Jesus' guest: A theology of the Open Table (2006). For the sake of brevity, our discussion here will not describe in detail the views offered in this resource, but points the reader to this work for a more thorough review of the theological stance held in this approach.

In short, the Open Table suggests that every person is welcome to participate in the Sacrament of Holy Communion and that there are no limitations or reservations on who may or who may not receive the elements. Although Methodist Laws and Discipline prescribe that the Sacrament is available to all who are baptised (2007:16-21), the practical outworking of this theology has been much broader. How does one, for instance, determine whether the homeless at the Central Methodist Mission have been baptised or not? How does a minister ask a family who kneel with their young child whether they have all been baptised? It has become common practice for those presiding over the Sacrament to welcome all without reservation or question and perhaps, as we explore the theology of the Open Table further, this will prove to be theologically equally sound.

Further to this, the Methodist Church has a very broad understanding of membership:

The conditions, privileges and duties of membership in the Methodist Church follow the tradition common to the Methodist People from the beginning. Membership is not conditional upon the profession of theological tenets, or dependent upon traditional authority or ecclesiastical ritual. It is based upon the personal experience of the Lord Jesus Christ, brought about by 
the Spirit, ranging from the earliest signs of Divine Grace in the soul to its crowning blessedness in the joy of 'perfect love', and upon the sharing of such gifts of grace with others seeking or enjoying a similar experience.

All persons are welcomed into membership who sincerely desire to be saved from their sins through faith in the Lord Jesus Christ and show the same in life and conduct, and who seek communion with Christ Himself and His people by taking up the duties and privileges of the Methodist Church.

(Methodist Church of Southern Africa 2007:25)

To be a member of the church means being part of the Church-universal and thus every person who responds to God's grace in faith should have free access to the Table.

Criticism may be levied that this practice breaks with the general theological understanding of who may and who may not be recipients of the Sacramental elements. Brand (1976:29) argues that the Sacrament of Holy Communion, especially to children, has been argued in history by both Roman Catholic and Reformed traditions on the grounds of the objectivity of sacramental grace. Communion is about identity; though not identification with a hierarchical or dogmatic system, but the identity of who a person is in a relationship with Christ and their place in community with other Christ-followers (Brand 1976:29).

At the same time, it has not always been the norm for the Church to require baptism or confirmation as a right for being admitted to the Table. It was only at the Fourth Lateran Council of 1215 that the Church pronounced that Confession precedes Communion, leading to first communion being celebrated with a child's first confession, usually at age seven (Brand 1976:37). There is no clear indication in Scripture that children, or the unbaptised, were either included or excluded from the Lord's Table in the early church. De Klerk (2007:611) explains that the celebration of Holy Communion in the early church was very closely linked to the hosting of a communal meal, where both rich and poor could sit around the same table. It was a table of hospitality where diversity was the norm. It is from this notion that Paul in his letter to the Corinthians (1 Cor 11:17-34) emphasised that the celebration of the Sacrament was not only to share in communion with Christ, but to remember one's relationship with other people. Those who participated in the Sacrament solely out of relationship with Christ, but who did not want to have anything to do with other people, brought judgement on themselves (De Klerk 2007:614).

The Open Table reflects the intention of inviting all to participate in the Sacrament whilst having the grace of God as the premise for this hospitality. It argues against the notion that one can earn the right of place at the Communion Table, whether through perceived righteousness, education or liturgical practice.

The notion of prevenient grace in the Methodist tradition then comes into play. Prevenient grace, as it is understood, is God's grace which goes before each person, and leads the person to where they can respond to God's grace through the gift of faith. It is for this reason that Wesley saw the Sacrament of Holy Communion as a means of grace (1987:126-127). Communion is not the initiative of the person, but is the message of God's grace made available for all in abundance:

The chief of these means [of grace] are prayer, whether private or public, Bible study (including reading, hearing and meditating), and receiving the Lord's Supper, the breaking of bread. I believe that these have been planned by God as the normal channels for conveying his grace and blessing to mankind [sic].

(Wesley 1987:126)

Prevenient grace is described in the participation of the Sacrament. If we were to argue that the Sacrament is only open to those who are either worthy or who understand the meaning of it, then no one would ever be able to participate. In fact, the first celebration of the Lord's Supper included those who were not worthy, perhaps Judas or Peter who would soon deny Jesus. It also included people who did not understand the significance of that moment. The disciples still believed that Jesus' Kingdom was an earthly kingdom and that His entry into Jerusalem would be the establishment of the Kingdom of God which was promised to Israel.

Hence, we witness the sons of Zebedee's request (or that of their mother), that they be seated at either side of Jesus when He took His place. What happened here? God's grace was made available first. It was a gift from God, the grace and love that goes before. It united those who understood with those who did not, those who would remain faithful to Jesus with those who would run away. It offered fellowship even to those who would prove to be instrumental in Jesus' death (Felton 2006:27-28).

Thus is the mystery of the inclusive nature of God's grace in the Sacrament. Calvin also confessed that if someone asked him the meaning of the Sacrament, that he would have no problem in admitting that the mystery of the Sacrament is more than he could understand or explain (Calvin's Institutes Book IV.xvii.32; De Klerk 2007:610)

Hooker (2006:101) offers the following criticism of this view: 'If everyone is welcome at the table, then we are no longer celebrating the church'. Perhaps Hooker is right, but it would depend on how one defines 'church'. If church consists only of those who have been accepted by a tradition or denomination through certain rites, then the Open Table would not celebrate the church. If, however, Church consists of everyone who responds to God's grace in faith, the inclusive Table would be the ideal celebration of this truth.

\section{How does the Sacrament of Holy Communion unite people?}

The Sacrament of Holy Communion brings about reconciliation through some considerations that need to be made clear as people share in the event. For this reason it is imperative for the person presiding over the Table to express the following points through the correct use of liturgy. 


\section{It is the Lord's Table}

The first point is that the Table at which people share is the Lord's Table, not your table or my table or even the church's table. It is the place where Christ invites people to share in the Sacramental meal. It is the place where those who share in the meal will be reminded of who Christ is and what Christ has done. For this reason 'Any gathering at the Lord's Supper is an "historical occasion" because this sacrament has to do with the historical, with what Christians think and believe about history' (Martin 1963:188).

For Methodist Christians, the remembrance of Christ is closely linked with whom Christ engages with and how this is done. Wesley was adamant that Christ's person and work was for all people, hence the later description of the Methodist doctrine of salvation as summarised in the following points: 'All people need to be saved, all people can be saved, all people can know that they are saved and all people can be saved to the uttermost' (Fitzgerald 1903). But, as is customary for all meals, there should be some form of preparation. As people are invited to the Lord's Table, all engage in a time of confession (Methodist Church Office 1975:B5-B6). The prayers of confession and the following prayers of intercession do not only focus on receiving forgiveness from God, but also places the participant in a position where forgiveness is sought from other people and forgiveness is offered in return. Before the meal is shared, time is allowed for the sharing of the peace (1975:B10).

This is not to say that the Table is then surrounded by people who are completely at peace with God or with each other. Although the peace may be shared, it is in the Sacrament that one is reminded of what God requires, and still, there may be animosity between some of the participants: 'Believers are called to manifest among themselves the unity achieved in Christ ... Conversely they are called to resist and banish every impulse toward social division and humiliation' (Hunsinger 2008:259). This is not unlike the first celebration of the Last Supper:

The Last Supper is a meal in the midst of conflict where Jesus names the conflicts in the room, and then gives bread, the gift of forgiveness, not a stone, or retribution, or punishment. In remembering the living reality, we are called to re-member or re-frame our world and our own actions so that we do likewise.

(Porter 2006a:18)

After naming the conflict, Jesus shares the bread and wine with every person, even Judas (Porter 2006a:20). The Sacrament does not wash over our sins or sinfulness or even our differences, but makes the participant profoundly aware of his or her need for grace: 'Grace is never manipulative, though it is always constitutive. It allows a measure of cooperation without ceasing to be what it is as the true origin or cause' (Hunsinger 2008:259). This grace is something only offered by God and becomes symbolically represented through the sharing at a Table which is not our own.

\section{Who is invited?}

The second matter revolves around the question: who exactly is invited to the Table? Charles Wesley (1954) put it very succinctly in a Communion hymn with the following words:

Come, sinners to the Gospel feast;

Let every soul be Jesu's guest;

Ye need not one be left behind,

For God hath bidden all mankind.

(Wesley 1954:123)

In the first line, people are reminded that we have all sinned, and if it were a matter of merit allowing people to participate in the Sacrament, then no-one would be able to participate. All are invited to the Table, to participate as the guests of Christ.

There may, at this point, be two reactions. Firstly, people may feel that they themselves are not worthy to come to the Table. Secondly, as people look around, they may think that others may not be worthy to come to the Table. The point of Communion is that Christ longs for unity in the Body and that no-one should for whatever reason feel that they are excluded from this celebration of grace. In his sermon entitled'The Catholic Spirit', John Wesley (1987) said the following:

Even among Christians it is difficult to find people who love one another in obedience to Jesus' command (John 13:34). There are two matters which stand in the way. The first is that Christians cannot all think alike; and in consequence the second is that they cannot all act alike.

(Wesley 1987:391)

The extent of God's grace is reflected in the physical occurrence where people of diverse views, even though harbouring negative feelings towards another, kneel together and are lifted above their differences to the common place of God's grace.

\section{Who is absent?}

As people participate around the Table, taking note of the diversity amongst those who gathered, participants are asked to think about those who are conspicuously absent from the Lord's Table. This reminder comes in the form of the prayers of intercession (Methodist Conference Office 1975:B7-B9):

One of the most faithful things that Christians can do as we participate in the Lord's Supper is consciously observe and reflect upon those who are absent from the Table. Are there those who feel shunned or unworthy? Are whole ethnic groups missing or scarcely represented? Are all socio-economic and educational classes included? Are children, the elderly, the infirm present? Are there persons with physical, emotional and mental incapacities? Are there persons of diverse sexual orientations and identities? Where are the poor, the homeless, the destitute? What about those confined to penal or custodial institutions? Who else among God's beloved people are absent?

(Felton 2006:32)

The point of this remembrance is that the representation at the Lord's Table speaks about the nature of Christian witness in that place. If all participants were of a homogenous nature, 
it may suggest that the Christian witness of that congregation does not reach those who are outside a certain demographic. The greater the diversity at the Lord's Table, the wider the net is thrown to declare the grace of God. The Open Table does not only give access to this means of grace to people who are able to participate in a worship service. The Methodist tradition allows for an extended Table, whereby elements that were consecrated at a celebration of the Lord's Table may be taken to those who, for whatever reason, may not be able to be present. It is common practice for lay people who have been suitably trained to take these elements to retirement villages, hospitals, shelters and prisons. By doing this, people from all walks of life are united around the same Table. The Judge who participated in the Sacrament at a worship service then shares around the same Table as the person whom they sentenced, the homeless share at the same Table with those living in wealth, and the list goes on.

The Sacrament allows participants to become instruments of reconciliation so that the next time the Sacrament is celebrated, those who were absent may hopefully be present and feel included:

We see the Table as a place where we receive the word of reconciliation but also where we are spiritually formed into reconcilers, empowered to name and give bread, empowered to practice reconciliation.

(Porter 2006a:22)

\section{Foretaste of things to come}

The fourth consideration is shared in the final prayers: 'Lord, You have fed us in this sacrament, united us with Christ and given us a foretaste of the heavenly banquet prepared for all mankind [sic]' (Methodist Conference Office 1975:B17). This prayer reminds participants that:

When we sit at this table we sit not only at the Table of the Last Supper, but also at the table of the messianic banquet ... The Kingdom of God has entered; its power is a present reality.

(Martin 1963:191)

To reflect on the Lord's Table, to be reminded that Christ invites, to acknowledge the presence of others and the absence of some, should challenge the church in its mission to work towards the complete reconciliation that is hoped for in the final banquet. If it were a literal banquet, then the belief, stemming from the celebration of Holy Communion in our time and space, would be that it would still be Christ who invites. People whom we did not expect to see there will be present and sharing in that meal. At the same time, there will be people who will be conspicuously absent.

This prayer speaks of the visionary nature of Holy Communion (Storey 2006:57). The Table is not, cannot and should not be a monument to division. It should reflect the nature of God's inclusion and grace, which comes as a surprise. This is the Pauline message to the community of faith in Corinth, which is summed up well in the following quotation regarding their Sacramental practice: 'It required believers not only to conform to Christ in His sacrificial self-giving, but also to rise above cultural antagonisms of religion, ethnicity, status and gender' (Hunsinger 2008:255). The heavenly banquet as the final consummation of the Sacrament's intention, we believe, will be the communion of people from very diverse backgrounds, even people who in this life may have seen themselves as being in conflict with one another.

\section{Conclusion}

In belonging to a congregation which celebrates an Open Table, it is wonderful to participate in the Sacrament when this significance is explained and the reality of reconciliation plays out at this important event in the life of the Church. There is something of the Kingdom of God in looking at those kneeling at the rail and finding, placed right next to each other, politicians with strongly opposed views, the elderly, children, people of all races, people with different sexual orientations, the wealthy, the homeless, the mentally and physically impaired, those with a strong faith and those who need this Sacrament as if it were their last meal.

And afterwards, this meal is shared with those who could not be present. The Sacrament of Holy Communion can truly be where people find reprieve from their differences in this world. As a means of grace, one can only pray that the diversity and unity shown around the Table will extend beyond the walls of the church to places of work, homes and the broader world.

By using the Sacrament in such a creative manner, without detracting from its historic and liturgical meaning and value, people may find the reality of the Kingdom in their midst and not merely see it as something which is reserved for the hereafter. The reality of unity, reconciliation and diversity is celebrated under the umbrella of God's grace in a tangible and physical action. It is here, by the Lord's invitation, that the lion lies down with the lamb, and those who were divided by whatever means can find common ground.

\section{Acknowledgements Competing interests}

The author declares that they have no financial or personal relationship(s) which may have inappropriately influenced them in writing this article.

\section{References}

Brand, E.L., 1976, 'Baptism and communion of infants: A Lutheran view', Worship 50(1), 29-42.

Calvin J., 2008, Institutes of the Christian religion, transl. H. Beveridge, Hendrickson Publishers, Peabody, MA.

Cavanagh, L., 2009, 'Reconciliation and renewal in Anglican life', Modern Believing $50(3), 42-48$

De Klerk, B.J., 2007, 'Die nagmaal en broodgebrek' [Communion and hunger], Hervormde Teologiese Studies 63(2), 605-624.

Felton, G.C., 2006, 'Holy Communion in the life of the church: The theology and experience of reconciliation', in T.W. Porter (ed.), Conflict and Communion: Reconciliation and restorative justice at Christ's Table, pp. 25-35, Upper Room Ministries, Nashville, TN

Fitzgerald, W.B., 1903, The roots of Methodism, Epworth Press, London. 
Hooker, D.A., 2006, 'Grandma's Supper is the Lord's Supper: The experience of African American fellowship meals and Sunday supper as Communion', in T.W. Porter (ed.), Conflict and Communion: Reconciliation and restorative justice at Christ's (ed.), Conflict and Communion: Reconciliation and restor
Table, pp. 101-112, Upper Room Ministries, Nashville, TN.

Hunsinger, G., 2008, The Eucharist and Ecumenism, Cambridge University Press, Cambridge, UK.

Keller, J., 1981, 'The linguistics of ecumenical theology: A preliminary assessment', Journal of Ecumenical Studies 18(2), 293-300.

Labi, K.A., 2001, 'Transforming ecumenism in Africa in the 21st century: The URM experience and challenge', Ecumenical Review 53(3), 366-373. http://dx.doi. org/10.1111/j.1758-6623.2001.tb00115.x

Martin, J.P., 1963, 'Belonging to history: A communion meditation on 1 Corinthians 11:23-26', Interpretation 17(2), 188-192.

Methodist Church of Southern Africa, 2006, Yearbook, Salty Print, Cape Town.

Methodist Church of Southern Africa, 1958, Minutes of the 75th Annual Conference of the Methodist Church of Southern Africa, Methodist Publishing House, Cape Town.

Methodist Church of Southern Africa, 2007, Laws and Discipline, 11th edn., Salty Print, Cape Town.

Methodist Conference Office, 1975, The Methodist service book, Methodist Publishing House, London.
Nelson, J.R., 1976, 'Methodist Eucharistic usage: From constant communion to benign neglect to sacramental recovery', Journal of Ecumenical Studies 13(2), 278-284.

Oestreicher, P., 2008, 'Reconciliation and renewal within the church', Modern Believing 49(2), 33-38.

Porter, T.W., 2006a, 'The Last Supper: Naming the conflicts and giving bread and wine', in T.W. Porter (ed.), Conflict and Communion: Reconciliation and restorative justice at Christ's Table, pp.17-24, Upper Room Ministries, Nashville, TN.

Porter, T.W. (ed.), 2006b, Conflict and Communion: Reconciliation and restorative justice at Christ's Table, Upper Room Ministries, Nashville, TN.

Stamm, M.W., 2006, Let every soul be Jesus' guest: A theology of the Open Table, Abingdon Press, Nashville, TN.

Storey, P.J., 2006, 'Table manners for peacemakers: Holy Communion in the life of peacemaking', in T.W. Porter (ed.), Conflict and Communion: Reconciliation and peacemaking', in T.W. Port's (ed), Conflict and Com Commion: Reconciliation and restorative justice at Christ's Table, pp. 57-66, Upper Room Ministries, Nashville,

Wesley, C., 1954, The Methodist Hymn Book and Methodist Service Book, Methodist Publishing House, London.

Wesley, J., 1987, Sermons on several occasions, transl. J.D. Holway, Moorley's Print and Publishing, Derbys. 